\title{
KINERJA RANGKAIAN SERI SISTEM MICROBIAL FUEL CELL SEBAGAI PENGHASIL BIOLISTRIK DARI LIMBAH CAIR PERIKANAN
}

\section{The Performance of Series Circuits in Microbial Fuel Cell's System from the Fisheries Wastewater}

\author{
Bustami Ibrahim ${ }^{\star}$ Pipih Suptijah dan Syeila Rosmalawati \\ Departemen Teknologi Hasil Perairan, Fakultas Perikanan dan Ilmu Kelautan, \\ Institut Pertanian Bogor, Kampus IPB Darmaga, Jalan Agatis, Bogor 16680 Jawa Barat \\ Telepon (0251) 8622909-8622906, Faks. (0251) 8622915 \\ *Korespondensi: bustamibr@yahoo.com, syeila.rosmalawati@yahoo.com \\ Diterima 04 Februari 2014/Disetujui 03 April 2014
}

\begin{abstract}
Abstrak
Listrik umumnya bersumber dari energi fosil yang merupakan sumber daya alam yang tidak dapat diperbaharui. Tingginya tingkat pemakaian energi yang tak terbarukan mendorong pencarian sumber energi alternatif baru. Salah satu teknologi yang dapat menjadi sumber energi alternatif baru adalah Microbial Fuel Cell. Microbial Fuel Cell adalah sistem yang memanfaatkan bakteri untuk mengoksidasi bahan organik dan anorganik. Teknologi tersebut dapat diaplikasikan pada limbah cair, misalnya limbah cair perikanan. Penelitian ini bertujuan untuk menguji kinerja penggunaan rangkaian seri bejana terhadap daya listrik yang dihasilkan limbah cair perikanan berdasar sistem Microbial Fuel Cell. Penelitian ini terdiri dari empat tahap, yaitu pembuatan limbah cair buatan, pembuatan perangkat alat Microbial Fuel Cell, pengukuran daya listrik, dan analisis kualitas limbah cair. Hasil daya listrik selama 120 jam pengamatan adalah $0,115 \mathrm{~V}$ untuk dua bejana, 0,259 V untuk tiga bejana, dan 0,534 V untuk empat bejana yang seluruhnya dirangkaikan secara seri. Hasil uji beban limbah cair menunjukkan penurunan pada COD, BOD, TAN dan total nitrogen, sedangkan MLSS dan MLVSS mengalami peningkatan dalam lima hari pengamatan.
\end{abstract}

Kata kunci: daya listrik, limbah cair perikanan, Microbial Fuel Cell, rangkaian seri

\section{Abstract}

Electricity source is generally from fossil energy that is natural resources and unrenewable. The use of non-renewable energy make us to find a new alternative energy. One of technologi which can make a new energy resource is Microbial Fuel Cell (MFC). Microbial Fuel Cell (MFC) is a system which uses the bacterium to oxidize inorganic and organic matters. The technology can apply on wastewater, for example the wastewater of fisheries. The purpose of this research was to find electrical power results from the performance of series circuits on the fisheries wastewater treatment by MFC's system. This research was done in four stages, those are artificial fisheries wastewater preparation, MFC's instrument installation, electrical power measurements, and analysis of the fisheries wastewater quality. Electrical potential resulted during 120 hours observation were $0.115 \mathrm{~V}$ for two vessels, $0.259 \mathrm{~V}$ for three vessels, and $0.534 \mathrm{~V}$ for four vessels which all of vessels arranged into series circuits. The results test of fisheries wastewater showed reducing in COD, BOD, TAN and total nitrogen, while MLSS and MLVSS increased in five days observations.

Keywords: electrical power, fisheries wastewater, Microbial Fuel Cell, series circuits

\section{PENDAHULUAN}

Perkembangan industri perikanan tidak hanya memberikan dampak positif tetapi juga telah memberikan dampak negatif, yaitu berupa buangan limbah. Limbah dari hasil kegiatan tersebut dapat berupa limbah padat dan limbah cair. Limbah padat terdiri dari bahan anorganik misal partikel pasir dan bahan organik misal pakan ikan. Limbah cair mengandung zat anorganik (terutama 
nitrogen dan fosfor) dan bahan organik (Priambodo et al. 2011). Limbah cair industri perikanan mengandung bahan organik yang tinggi, ditandai dengan biological oxygen demand, total suspended solids, dan total Kjeldahl nitrogen yang tinggi. Limbah industri perikanan yang dibuang langsung ke perairan umum tanpa pengolahan terlebih dahulu akan mencemari lingkungan, yaitu menyebabkan bau, eutrofikasi perairan, dan pendangkalan (Ibrahim et al. 2009 ${ }^{\mathrm{b}}$ ). Tingkat pencemaran limbah cair industri perikanan sangat tergantung pada tipe proses pengolahan dan spesies ikan yang diolah (Ibrahim 2005).

Teknologi pengolahan limbah cair adalah kunci dalam memelihara kelestarian lingkungan. Teknologi pengolahan limbah cair yang dibangun harus dapat dioperasikan dan dipelihara oleh pihak-pihak terkait. Teknologi pengolahan limbah cair yang telah dikembangkan secara umum terbagi menjadi tiga metode pengolahan, yaitu pengolahan secara fisika, pengolahan secara kimia, dan pengolahan secara biologis (Metcalf dan Eddy 1991).

Tujuan pengolahan limbah cair secara biologis adalah menurunkan komponen terlarut, khususnya senyawa organik sampai pada batas yang aman terhadap lingkungan dengan memanfaatkan mikroorganisme dan/atau tanaman (Ibrahim 2005). Mikroorganisme mengonsumsi bahan-bahan organik membuat biomassa sel baru serta zat-zat organik dan memanfaatkan energi yang dihasilkan dari reaksi oksidasi untuk metabolismenya (Oktavia et al. 2012). Salah satu pengolahan biologis limbah cair dapat dilakukan dengan penambahan lumpur aktif (Edahwati dan Suprihatin 2009).

Lumpur aktif merupakan gumpalan partikel yang mengandung campuran mikroorganisme aerobik yang dihasilkan melalui proses aerasi (Jenie dan Rahayu 1993). Menurut Suyanto et al. (2010) berbagai jenis biomassa terdapat melimpah di wilayah Indonesia terutama pada limbah. Penelitian terkini membuktikan adanya potensi penggunaan limbah cair sebagai penghasil energi masa depan, khususnya energi listrik.

Salah satu metode dalam pengolahan limbah cair menjadi energi adalah biofuel cell. Beberapa tipe biofuel cell antara lain Microbial Fuel Cells dan enzymatic fuel cells (Kim et al. 2002). Microbial Fuel Cell (MFC) adalah sistem yang memanfaatkan bakteri untuk mengoksidasi bahan organik dan anorganik. Prinsip kerja sistem MFC adalah bakteri pada bejana memproduksi elektron kemudian dipindah ke anoda dan dialirkan ke katoda yang disambungkan oleh perangkat konduktivitas untuk menghasilkan listrik yang dapat menjalankan alat (Logan 2008).

Mekanisme transfer elektron di anoda MFC adalah isu utama dalam memahami teori bagaimana MFC bekerja. Mikroba memindahkan elektron melalui sistem pengangkutan elektron yang terdiri dari serangkaian komponen matriks ekstraseluler bakteri atau bersama-sama dengan pemindahan elektron dilarutkan dalam solusi massal (Du et al. 2007).

Penggunaan mikroorganisme dalam biofuel cell dapat menghilangkan isolasi enzim individu sehingga memberikan substrat yang lebih murah untuk bahan bakar sel. Listrik telah dihasilkan menggunakan sumber energi kebutuhan kompleks termasuk air limbah (Scott dan Murano 2007). Bakteri di dalam MFC bisa digunakan untuk memproduksi listrik selama mengonsumsi limbah (Milliken dan May 2007).

Berbagai studi mengenai MFC telah dilakukan. Sistem MFC dilakukan terhadap elektroda (Cheng et al. 2006), desain reaktor MFC (Liu dan Logan 2004), jenis bakteri yang digunakan (Nimje et al. 2009), dan jenis substrat yang digunakan (Moon et al. 2006). Sistem MFC telah dikembangkan sebagai teknologi dalam pengolahan limbah hasil perikanan (You et al. 2009) dan mengurangi tingkat pencemaran lingkungan perairan (Oh et al. 2010). Sistem MFC diharapkan dapat menekan biaya pengolahan limbah menghasilkan sumber energi listrik baru 
dengan biaya murah dan ramah lingkungan.

Penelitian mengenai penggunaan sistem MFC masih terbatas. Industri umumnya belum mengetahui tentang sistem MFC dalam pengolahan limbah cair yang sebenarnya dapat menekan biaya operasional perusahaan tersebut. Informasi mengenai rangkaian yang dapat digunakan dalam sistem MFC belum digali secara optimal, sehingga hal inilah yang melatarbelakangi dilakukan penelitian pemanfaatan limbah cair perikanan menggunakan sistem MFC yang disusun secara rangkaian seri. Penelitian ini bertujuan untuk mengidentifikasi kinerja penggunaan rangkaian seri terhadap daya listrik yang dihasilkan limbah cair perikanan dengan sistem MFC.

\section{BAHAN DAN METODE}

\section{Bahan dan Alat}

Bahan-bahan yang digunakan pada penelitian ini antara lain lumpur aktif, limbah cair ikan, akuades, $\mathrm{K}_{2} \mathrm{Cr}_{2} \mathrm{O}_{7} 0,025 \mathrm{~N}$, $\mathrm{H}_{2} \mathrm{SO}_{4}, \mathrm{Ag}_{2} \mathrm{SO}_{4}$, indikator ferroin, ferrous ammonium sulfat $\left[\mathrm{Fe}\left(\mathrm{NH}_{4}\right)_{2}\left(\mathrm{SO}_{4}\right)_{2}\right], \mathrm{NaOH}$ pekat, asam borat $\left(\mathrm{H}_{3} \mathrm{BO}_{3}\right) 4 \%$, indikator bromcherosol green dan methyl red, $\mathrm{HCl}$, asam hypochlorous, reagen phenate, dan kertas saring Whatman 42.

Alat-alat yang digunakan pada penelitian ini antara lain, kaca acrylic, elektroda karbon grafit berbentuk batang, kabel, multimeter digital tipe DT $830 \mathrm{~B}$, timbangan digital (Tanita KD 160), Kjeldahl (Labentech), botol
Erlenmeyer, buret, pipet, botol DO, DO meter (Lutron DO5510), Air pump atau aerator, spektrofotometer (Optima SP-300), oven (Yamato Drying Oven DV 41), tanur (Yamato Muffle Furnace FM 38), cawan porselen, kompor listrik, dan desikator.

\section{Metode Penelitian}

Metode yang digunakan dalam penelitian ini adalah metode percobaan.Penelitian ini terdiri dari 4 tahap. Tahap pertama yaitu pembuatan limbah cair buatan (Fauzi et al. 2003 diacu dalam Ibrahim et al. 2009a), tahap kedua adalah pembuatan alat MFC satu bejana mengacu pada Moqsud dan Omine (2010) yang dimodifikasi dalam peletakan elektroda (Gambar 1a) dan rangkaian bejana yang disusun secara seri yang terdiri atas dua, tiga, dan empat bejana (Gambar 1b). Setiap bejana dilakukan penambahan lumpur aktif dengan rasio antara lumpur aktif dengan limbah cair perikanan yaitu 1:10 yang mengacu pada Patil et al. (2009).

Tahap ketiga adalah pengukuran listrik dari MFC satu bejana mengacu pada Suyanto et al. (2010). Nilai elektrisitas yang dihasilkan oleh sistem MFC diukur menggunakan multimeter setiap satu jam sekali selama 120 jam dalam satuan volt (V). Tahap keempat adalah analisis kualitas limbah cair yang terdiri dari analisis chemical oxygen demand (COD), biological oxygen demand (BOD), total amonia nitrogen (TAN), total Kjeldahl nitrogen (TKN), mixed liquor suspended solids

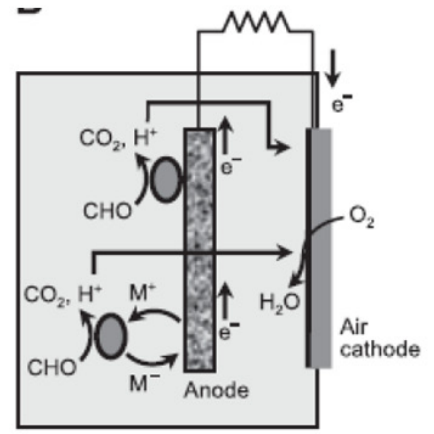

(a)

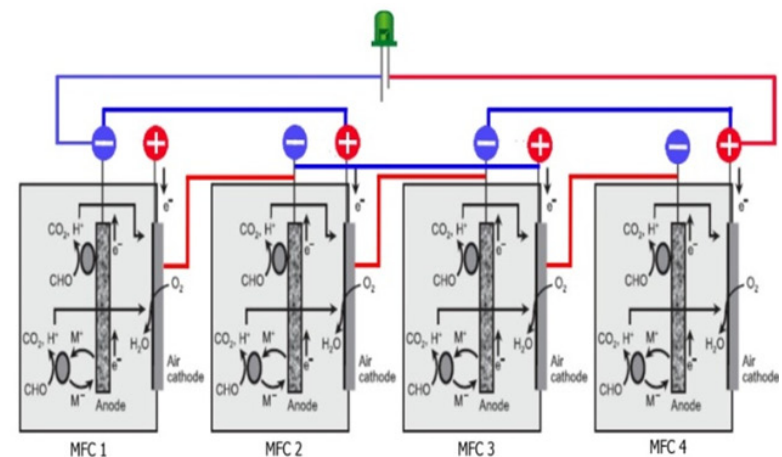

(b)

Gambar 1 (a) Desain system MFC satu bejana (Liu dan Logan 2004); (b) Desain MFC dengan rangkaian seri. 
(MLSS) dan mixed liquor volatile suspended solids (MLVSS).

\section{HASIL DAN PEMBAHASAN}

\section{Karakteristik Limbah Cair Buatan}

Limbah cair buatan memiliki kadar BOD $124 \mathrm{mg} / \mathrm{L}$ (Tabel 1). Nilai BOD tersebut lebih rendah dibandingkan dengan limbah cair penelitian Ibrahim (2007) yaitu $184 \mathrm{mg} / \mathrm{L}$. Limbah cair buatan memiliki kadar COD 768 $\mathrm{mg} / \mathrm{L}$, kadar amonia 2,44 mg/L, dan kadar total nitrogen 3.464,51 mg/L. Kadar COD, amonia, dan total nitrogen lebih tinggi dibandingkan penelitian Ibrahim (2007) dengan nilai kadar COD $571 \mathrm{mg} / \mathrm{L}$, kadar amonia 1,7 mg/L, dan kadar total nitrogen $111 \mathrm{mg} / \mathrm{L}$.

Kadar COD, amonia, dan total nitrogen yang tinggi menunjukkan beban kandungan organik pada limbah cair buatan perlu dikurangi sesuai dengan standar sehingga diperlukan penambahan lumpur aktif sebagai upaya pengurangan beban limbah cair. Lumpur aktif merupakan gumpalan partikel yang mengandung campuran mikroorganisme aerobik yang dihasilkan melalui proses aerasi. Prinsip kerja dari lumpur aktif adalah memanfaatkan mikroorganisme yang dapat menguraikan senyawa organik dalam limbah cair secara aerobik menjadi sumber tenaga, bahan seluler baru, air dan karbondioksida (Jenie dan Rahayu 1993).

\section{Karakteristik Limbah Cair Perikanan pada Sistem MFC}

Kadar Chemical Oxygen Demand (COD)

Limbah awal memiliki kadar COD 768 $\mathrm{mg} / \mathrm{L}$ dan limbah akhir memiliki kadar COD
$384,77 \pm 185,63 \mathrm{mg} / \mathrm{L}$, dengan penurunan yang terjadi yaitu 49,90\%. Penurunan kadar COD disebabkan mikroorganisme mendegradasi bahan organik yang terdapat dalam limbah cair. Penambahan lumpur aktif akan meningkatkan jumlah mikroorganisme yang terdapat dalam limbah cair sehingga dapat mempercepat proses degradasi senyawa organik limbah cair. Kadar COD limbah cair perikanan masih di atas nilai baku mutu limbah cair tepung ikan yaitu 300 mg/L (Kementerian Lingkungan Hidup 2007). Kadar COD yang masih tinggi menunjukkan bahwa kandungan organik limbah belum seluruhnya terdegradasi.

\section{Kadar Biological Oxygen Demand (BOD)}

Limbah cair awal memiliki kadar BOD $124 \mathrm{mg} / \mathrm{L}$, sedangkan limbah cair akhir memiliki kadar BOD 54,67 $\pm 14,74 \mathrm{mg} / \mathrm{L}$, dengan penurunan BOD yang terjadi 55,91\%. Penurunan BOD disebabkan mikroorganisme tumbuh dan berkembang biak menggunakan bahan organik yang terdapat dalam limbah cair yang didukung dengan ketersediaan oksigen yang cukup dengan adanya proses pengadukan. Kadar BOD yang tinggi mencerminkan konsentrasi bahan organik yang tinggi sehingga diperlukan oksigen yang tinggi (Poppo et al. 2008). Kementerian Lingkungan Hidup 2007 menetapkan nilai baku mutu limbah cair tepung ikan yaitu 100 $\mathrm{mg} / \mathrm{L}$ dan nilai BOD yang diperoleh pada penelitian di bawah baku mutu tersebut.

\section{Kadar Total Amonia Nitrogen (TAN)}

Limbah awal memiliki kadar TAN 2,44 mg/L, sedangkan limbah akhir memiliki

Tabel 1 Karakteristik limbah cair buatan

\begin{tabular}{|c|c|c|c|}
\hline Parameter & $\begin{array}{c}\text { Limbah cair } \\
\text { buatan }(\mathrm{mg} / \mathrm{L})\end{array}$ & $\begin{array}{c}\text { Limbah cair perikanan }^{\text {a }} \\
(\mathrm{mg} / \mathrm{L})\end{array}$ & $\begin{array}{c}\text { Baku mutu limbah cair } \\
\text { tepung ikan }{ }^{\mathrm{b}}(\mathrm{mg} / \mathrm{L})\end{array}$ \\
\hline BOD5 & 124 & 184 & 100 \\
\hline COD & 768 & 571 & 300 \\
\hline Amonia & 2,44 & 1,7 & 5 \\
\hline Total N & & 111 & \\
\hline
\end{tabular}

Sumber: ${ }^{\mathrm{I}} \mathrm{b}$ brahim (2007); ${ }^{\mathrm{b}} \mathrm{Kementrian}$ Negara Lingkungan Hidup (2007). 
kadar TAN 1,38 $\pm 0,13 \quad \mathrm{mg} / \mathrm{L}$, dengan penurunan yang terjadi $43,37 \%$. Penurunan kadar TAN disebabkan terjadinya proses nitrifikasi sehingga membutuhkan oksigen yang konstan. Penanganan limbah cair yang mengandung nitrogen organik yang tinggi seperti pada limbah cair industri perikanan, dapat dilakukan dengan cara biologis melalui proses nitrifikasi dan denitrifikasi, yang pada umumnya dilakukan dalam suatu sistem yang berkelanjutan (Ibrahim et al. 2009ª).

\section{Kadar Total Kjeldahl Nitrogen (TKN)}

Limbah awal memiliki nilai sebesar 3.464,51 mg/L, sedangkan limbah akhir memiliki nilai 2.136,24 $\mathrm{mg} / \mathrm{L}$, dengan penurunan yang terjadi $38,34 \%$. Penurunan total nitrogen disebabkan terjadinya proses penguraian senyawa nitrogen dalam limbah cair, namun total nitrogen masih tinggi. Total $\mathrm{N}$ yang tinggi dapat disebabkan oleh masih terdapatnya kandungan ammonia yang belum teroksidasi dan padatan tersuspensi yang tersisa di dalam limbah cair. Menurut Kim et al. (2002), salah satu metode yang dapat digunakan untuk meyisihkan nitrogen secara biologis adalah proses nitrifikasi dan denitrifikasi. Menurut Fux dan Siegrist (2004), degradasi material organik limbah cair oleh mikroba melalui nitrifikasi, denitrifikasi, dan proses lain dapat dilihat melalui jumlah nitrogennya.

\section{Kadar Mixed Liquor Suspended Solids (MLSS) dan Mixed Liquor Volatile Suspended Solids (MLVSS)}

Limbah awal MLSS menunjukkan nilai $2.800 \pm 282,84 \mathrm{mg} / \mathrm{L}$ dan limbah akhir $5.800 \pm 848,53 \mathrm{mg} / \mathrm{L}$. Hasil uji MLVSS yaitu $2.100 \pm 141,42 \mathrm{mg} / \mathrm{L}$ dan limbah akhir $4.400 \pm 565,68 \mathrm{mg} / \mathrm{L}$. Kadar MLSS mengalami peningkatan $51,72 \%$ dan peningkatan MLVSS $52,27 \%$. Peningkatan nilai MLSS dan MLVSS karena semakin lama hari pengamatan maka semakin banyak materi organik yang terdegradasi oleh mikroorganisme pada lumpur aktif yang memanfaatkannya sebagai nutrisi untuk pertumbuhan. Peningkatan nilai MLSS dan MLVSS sesuai dengan pernyataan Whalen et al. (2006) bahwa peningkatan waktu kontak antara mikroorganisme dalam limbah akan menghasilkan pertumbuhan mikroba yang dapat menghilangkan polutan berkadar organik tinggi sehingga nilai uji ini menunjukkan kandungan material organik yang terdapat dalam limbah cair beserta peningkatan biomassanya.

\section{Elektrisitas Sistem MFC Limbah Cair Perikanan}

Semua perlakuan baik dua, tiga, maupun empat bejana yang dirangkaikan secara seri, menunjukkan semakin banyak bejana yang dirangkaikan secara seri maka semakin tinggi nilai elektrisitas yang dihasilkan. Elektrisitas yang dihasilkan memiliki nilai yang berfluktuasi pada setiap perlakuan. Nilai elektrisitas rata-rata jam ke-0 yaitu $0,009 \mathrm{~V}$ pada dua bejana (Gambar 2), 0,31 V pada tiga bejana (Gambar 3), dan 0,523 V pada empat bejana (Gambar 4).

Gambar 2 menunjukkan nilai elektrisitas dua bejana yang disusun secara seri. Berdasarkan Tabel 2, elektrisitas tertinggi ditunjukkan pada jam ke-110 dengan nilai $0,733 \mathrm{~V}$ dan terendah ditunjukkan pada jam ke-0 dengan nilai $0,009 \mathrm{~V}$. Nilai elektrisitas mengalami fluktuasi pada jam ke-111 hingga hari terakhir proses pengukuran. Nilai elektrisitas rata-rata yang dihasilkan sistem MFC dua bejana selama pengukuran yaitu $0,1151 \mathrm{~V}$.

Gambar 3 menunjukkan nilai elektrisitas tiga bejana yang disusun secara seri. Berdasarkan Tabel 2, elektrisitas tertinggi ditunjukkan pada jam ke-49 dengan nilai $0,713 \mathrm{~V}$ dan terendah ditunjukkan pada jam ke-90 dengan nilai 0,02 V. Elektrisitas mengalami penurunan setelah jam ke-90, namun elektrisitas mengalami peningkatan kembali pada jam ke-115 hingga hari terakhir pengukuran. Nilai elektrisitas rata-rata yang dihasilkan sistem MFC tiga bejana selama lima hari pengukuran yaitu $0,2595 \mathrm{~V}$. 


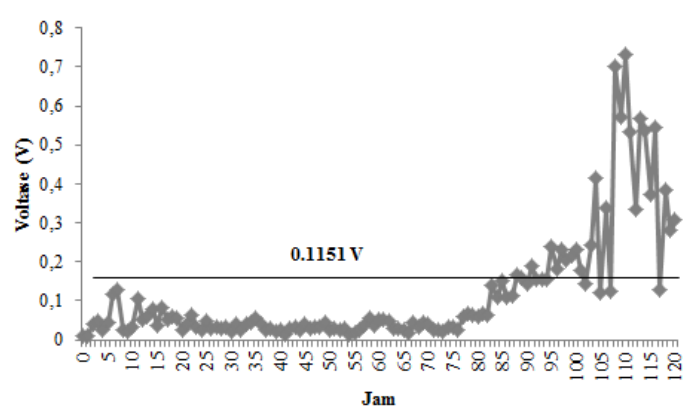

Gambar 2 Nilai elektrisitas rangkaian seri 2 bejana.

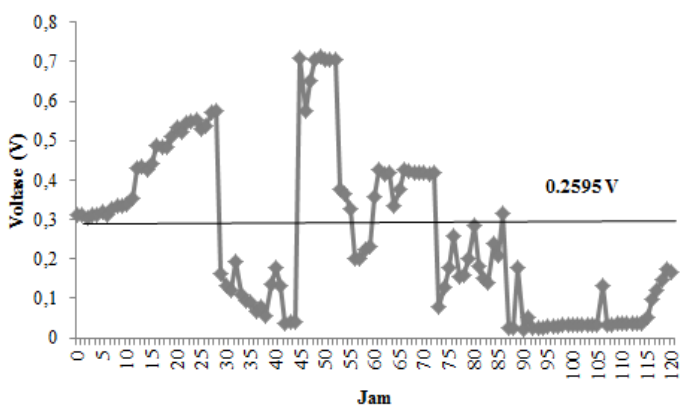

Gambar 3 Nilai elektrisitas rangkaian seri 3 bejana.

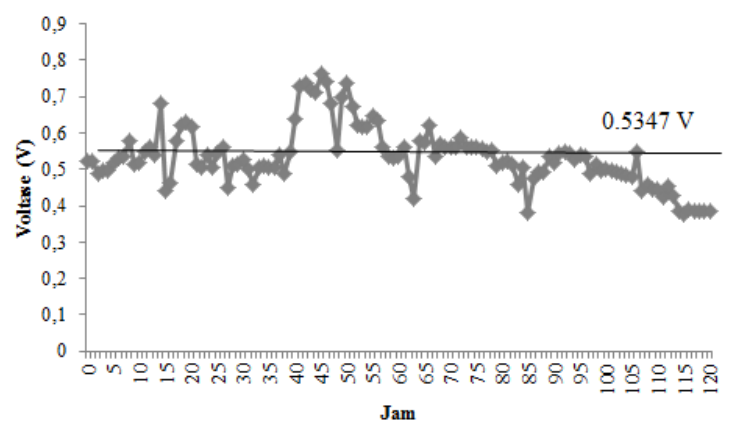

Gambar 4 Nilai elektrisitas rangkaian seri 4 bejana.

Tabel 2 Hasil elektrisitas rangkaian seri

\begin{tabular}{ccccc}
\hline Parameter & Jam ke- & Voltase Tertinngi (V) & Jam ke- & Voltase Terendah (V) \\
\hline Seri 2 bejana & 110 & 0,733 & 0 & 0,1151 \\
Seri 3 bejana & 49 & 0,713 & 90 & 0,2595 \\
Seri 4 bejana & 45 & 0,763 & 115 & 0,5347 \\
\hline
\end{tabular}

Gambar 4 menunjukkan nilai elektrisitas empat bejana yang disusun secara seri. Berdasarkan Tabel 2, elektrisitas tertinggi ditunjukkan pada jam ke-45 dengan nilai $0,763 \mathrm{~V}$, sedangkan elektrisitas terendah ditunjukkan pada jam ke-115 dengan nilai 0,376 V. Listrik yang dihasilkan berfluktuasi mengalami peningkatan dan penurunan di hari terakhir pengukuran. Nilai elektrisitas rata-rata yang dihasilkan sistem MFC empat bejana selama lima hari pengukuran yaitu $0,5347 \mathrm{~V}$.

Potensial listrik yang terukur berasal dari kemampuan MFC sebagai bioelectrochemical system (BESs) yang dapat mengubah biomassa menjadi energilistrik melalui aktivitas mikroba (Pant et al. 2009). Fluktuasi listrik yang terjadi selama lima hari diduga karena interaksi dan persaingan yang terjadi antara bakteri di dalam substrat pertumbuhan. Peningkatan atau penurunan nilai elektrisitas berkaitan dengan elektron yang dapat berikatan dengan TEA (Terminal Electron Acceptor) misalnya oksigen, nitrat, nitrit, sulfat, dan sebagainya yang berdifusi melalui sel. Elektron tersebut ditangkap oleh anoda dan proton ditangkap oleh katoda yang kemudian menyebabkan beda potensial sehingga menghasilkan biolistrik (Logan 2008).

Peningkatan nilai elektrisitas yang terukur oleh multimeter kemungkinan terjadi saat mikroba melakukan pemecahan substrat sederhana yang terdapat di dalam medium. Penurunan listrik yang terjadi kemungkinan juga disebabkan oleh mikroba yang sedang beradaptasi untuk memecah substrat yang lebih kompleks menjadi sederhana. Peningkatan dan penurunan nilai elektrisitas menunjukkan kedinamisan sistem karena digerakkan oleh makhluk hidup. Menurut Ieropoulos et al. (2008), selama periode yang sangat singkat, mikroorganisme masih dalam 
keadaan transisi untuk beradaptasi dengan sistem MFC karena resistensi internal yang bervariasi. Faktor-faktor yang mempengaruhi resistansi internal yaitu elektroda, kandungan larutan elektrolit, dan proton. Resistansi internal elektroda tergantung pada kuantitas dan konduktivitas materi serta bentuk dan komposisinya.

Sistem MFC dengan penambahan lumpur aktif juga dipengaruhi oleh proses pengadukan. Pengadukan berperan penting karena dapat menjaga kestabilan kelarutan bahan organik yang digunakan metabolisme mikroorganisme. Hasil penelitian Winaya et al. (2011), bakteri anaerob dan material organik harus dikondisikan stabil pada suatu lingkungan agar material organik dapat dikonversi menjadi energi listrik. Lovely (2006) menyatakan bahwa komponen material limbah merupakan faktor penting dalam perubahan limbah organik menjadi bioenergi yang dapat menghasilkan listrik.

Listrik yang dihasilkan melalui sistem MFC yang disusun secara seri umumnya memiliki nilai elektrisitas yang lebih tinggi dibandingkan nilai elektrisitas sistem MFC yang disusun secara paralel. Penelitian ini menghasilkan listrik rata-rata $0,1151 \mathrm{~V}$ untuk dua bejana, $0,2595 \mathrm{~V}$ untuk tiga bejana, dan 0,5347 V untuk empat bejana. Penelitian Aelterman et al. (2006) diperoleh tegangan rangkaian terbuka $0,67 \mathrm{~V}$ untuk sambungan paralel dan 4,16 V untuk sambungan seri. Pengukuran output daya maksimum untuk rangkaian seri memiliki tegangan yang lebih tinggi dari $2.279 \mathrm{mV}$ (49 mA), sedangkan paralel memiliki tegangan $269 \mathrm{~mA}$ pada $354 \mathrm{mV}$. Sistem MFC yang dihubungkan secara seri bekerja masing-masing pada arus dan tegangan rata-rata yang ditentukan oleh kinerja MFC individu. Sistem MFC secara seri tidak akan memberikan densitas kekuatan yang lebih tinggi dibandingkan dengan MFC individu tetapi MFC seri dapat menciptakan kemungkinan untuk menghasilkan daya ratarata tegangan dan arus yang lebih praktis.

Arus maksimum ditentukan oleh tiga faktor. Pertama, desain MFC yang menentukan kerugian elektrokimia (misalnya, resistansi internal) dan keterbatasan transportasi konvektif. Kedua, beban volumetrik yang merupakan jumlah total elektron dialirkan oleh substrat. Ketiga, jumlah substrat diubah menjadi listrik (efisiensi Coulomb). Kerugian elektrokimia dalam sistem MFC dikategorikan sebagai (i) kerugian aktivasi yang dapat diturunkan oleh nanowires, (ii) kerugian ohmik yang ditentukan oleh resistensi dari elektrolit dan elektroda, dan (iii) kerugian perpindahan massa yang terjadi karena penurunan reaktan pada permukaan elektroda (Aelterman et al. 2006).

\section{KESIMPULAN}

Sistem teknologi Microbial Fuel Cell dengan penambahan lumpur aktif dapat diterapkan pada limbah cair perikanan untuk menghasilkan biolistrik. Karakteristik limbah cair perikanan memiliki nilai COD $768 \mathrm{mg} / \mathrm{L}$, BOD $124 \mathrm{mg} / \mathrm{L}$, amonia 2,44 mg/L dan total nitrogen $3.464,51 \mathrm{mg} / \mathrm{L}$.

Penambahan lumpur aktif dapat menurunkan beban limbah cair yang dapat dilihat dari penurunan nilai COD, BOD, TAN, dan total nitrogen serta peningkatan nilai MLSS dan MLVSS. Penyusunan rangkaian seri yang digunakan dalam sistem MFC menunjukkan nilai elektrisitas yang lebih optimal dengan rata-rata nilai elektrisitas dua bejana yang dirangkaikan seri yaitu $0,1151 \mathrm{~V}$, nilai elektrisitas tiga bejana yang dirangkaikan seri yaitu $0,2595 \mathrm{~V}$ dan $0,5347 \mathrm{~V}$ untuk empat bejana yang dirangkaikan seri.

\section{DAFTAR PUSTAKA}

Aelterman P, Rabaey K, Pham HT, Boon N, Verstraete W. 2006. Continuous electricity generation at high voltages and currents using stacked Microbial Fuel Cells. Environmental Science \& Technology 40: 3388-3394.

Cheng S, Liu H, Logan BE. 2006. Increased performance of single-chamber Microbial Fuel Cell using an improved chatode 
structure. Electrochemical Community 8: 489-494.

Du Z, Li H, Gu T. 2007. A state art review on Microbial Fuel Cells: a promising technology for wastewater treatment and bioenergy. Biotechnology Advances 25: 464-482.

Edahwati L, Suprihatin. 2009. Kombinasi proses aerasi, adsorpsi, dan filtrasi pada pengolahan air limbah industri perikanan. Jurnal Ilmiah Teknik Lingkungan 1(2):7983.

Fux C, Siegrist H. 2004. Nitrogen removal from sludge digester liquids by nitrification/denitrification or partial nitritation/anammox: environmental and economical considerations. Water Science and Technology 50(10):19-26.

Ibrahim B. 2005. Kaji ulang sistem pengolahan limbah cair industri hasil perikanan secara biologis dengan lumpur aktif. Buletin Teknologi Hasil Perikanan 13(1): 31-40.

Ibrahim B. 2007. Studi penyisihan nitrogen air limbah agroindustri hasil perikanan secara biologis dengan model dinamik activated sludge model (ASM) 1. [disertasi]. Bogor: Sekolah Pasca Sarjana Institut Pertanian Bogor.

Ibrahim B, Erungan AC, Heriyanto. 2009a. Nilai parameter biokinetika proses denitrifikasi limbah cair industri perikanan pada rasio COD/TKN yang berbeda. Jurnal Pengolahan Hasil Perikanan Indonesia 12(1): 31-45.

Ibrahim B, Suptijah P, Prantommy. 2009b. Pemanfaatan kitosan pada pengolahan limbah cair industri perikanan. Jurnal Pengolahan Hasil Perikanan Indonesia 12(2): 154-166.

Ieropoulos I, Greenman J, Melhuish C. 2008. Microbial Fuel Cells based on carbon veil electrodes: stack configuration and scalability. International Journal of Energy Research 32(13): 1228-1240.

Jenie BSL, Rahayu WP. 1993. Penanganan Limbah Industri Pangan. Yogyakarta:
Kanisius.

Kementerian Negara Lingkungan Hidup. 2007. Keputusan Menteri No. 6 Tahun 2007 tentang Baku Mutu Air Limbah Bagi Usaha dan/atau Kegiatan Pengolahan Hasil Perikanan. Jakarta: Kementerian Lingkungan Hidup.

Kim HJ, Park HS, Hyun MSD, Chang IS, Kim M, Kim BH. 2002. A mediator-less Microbial Fuel Cell using a metal reducing bacterium, Schewanella putreficiens. Enzyme and Microbial Technology 30: 145-152.

Liu H, Logan BE. 2004. Electicity generation using an air-chatode single chamber Microbial Fuel Cell in the presence and absence of a proton exchange membrane. Environmental Science and Technology 38: 4040-4046.

Logan BE. 2008. Microbial Fuel Cell. United States of America: A John Wiley \& Sons Inc.

Lovely DR. 2006. Bug juice: harvesting electricity with microorganisms. Nature Reviews 4: 497-508.

Metcalf, Eddy. 1991. Wastewater Engineering: Treatment, Disposal and Reuse 3rd Edition. Singapore: McGraw Hill Inc.

Milliken CE, May HD. 2007. Sustained generation of electricity by the spore-forming, gram positive, Desulfitobacterium hafniense strain DCB2. Applied Microbial and Cell Physiology 73:1180-1189.

Moon H, Chang IS, Kim BH. 2006. Continuous electricity production from artificial wastewater using a mediatorless Microbial Fuel Cell. Bioresource Technology 97:621-627.

Mosqud MA, Omine K. 2010. Bio-electricity generation by using organic waste in Bangladesh. International Journal of Environmental 7:122-124.

Nimje VR, Chen CY, Chen CC, Jean JS, Reddy AS. 2009. Stable and high energy generation by a strain of Bacillus subtilis in a Microbial Fuel Cell. Journal Power 
Sources. in press.

Oh ST, Kim JR, Premier GC, Lee TH, Kim J, Changwon K, Sloan WT. 2010. Sustainable wastewater treatment: how might Microbial Fuel Cells contribute. Journal Biotechnology 28:871-881.

Oktavia DA, Mangunwidjaja D, Wibowo S, Sunarti TC, Rahayuningsih M. 2012. Pengolahan limbah cair perikanan menggunakan konsorsium mikroba indigenous proteolitik dan lipolitik. AGROINTEK 6(2): 65-71.

Pant D, Bogaert GV, Diels L, Vanbroekhoven K. 2009. A review of the substrates used in Microbial Fuel Cells (MFCs) for sustainable energy production. Bioresource Technology. Article in press: 1-11.

Patil SA, Surakasi VP, Koul S, Ijmulwar S, Vivek A, Shouche YS, Kapadnis BP. 2009. Electricity generation using chocolate industry wastewater and its treatment in activated sludge based Microbial Fuel Cell and analysis of developed microbial community in the anode chamber. Bioresource Technology 100: 5132-5139.

Poppo A, Mahendra MS, Sundra IK. 2008. Studi kualitas perairan pantai di kawasan industri perikanan desa Pengambengan, Kecamatan Negara, Kabupaten Jembrana. Ecotrophic 3(2): 98-103.

Priambodo G, Mangkoedihardjo S, Hadi W,
Soedjono ES. 2011. Wastewater treatment strategy for fish processing industry in Kota Pantai Muncar of Indonesia. International Journal of Academic Research 3(2):93-97.

Scott K, Murano C. 2007. Microbial Fuel Cells utilizing carbohydrates. Journal of Chemical Technology and Biotechnology 82:92-100.

Suyanto E, Mayangsari A, Wahyuni A, Zuhro F, Isa S, Sutariningsih SE, Retnaningrum E. 2010. Pemanfaatan limbah cair domestic IPAL kricak sebagai substrat generator elektrisitas melalui teknologi Microbial Fuel Cell ramah lingkungan. Seminar Nasional Biologi di Yogyakarta 24-25 September 2010.

Whalen PA, Whalen PJ, Tracey DR. 2006. Cellular ATP-a superior measure of active biomass for biological wastewater treatment processes. WEFTEC 6:30253037

Winaya INS, Sucipta M, Putra A. 2011. Memanfaatkan air bilasan bagas untuk menghasilkan listrik dengan teknologi Microbial Fuel Cell. Jurnal Ilmiah Teknik Mesin Cakram 5(1): 57-63.

You SJ, Ren NQ, Zhao QL, Wang JY, Yang FL. 2009. Power generation and electrochemical analysis of biocathode Microbial Fuel Cell using graphite fiber brush as cathode material. Journal Fuel Cells 5: 588-596. 